Document downloaded from:

http://hdl.handle.net/10251/38315

This paper must be cited as:

Gil Pechuán, I.; Expósito Langa, M.; Tomas Miquel, JV. (2013). International entrepreneurship in SMEs: a study of influencing factors in the textile industry. International Entrepreneurship and Management Journal. 9(1):45-57. doi:10.1007/s11365-012-0242-3.

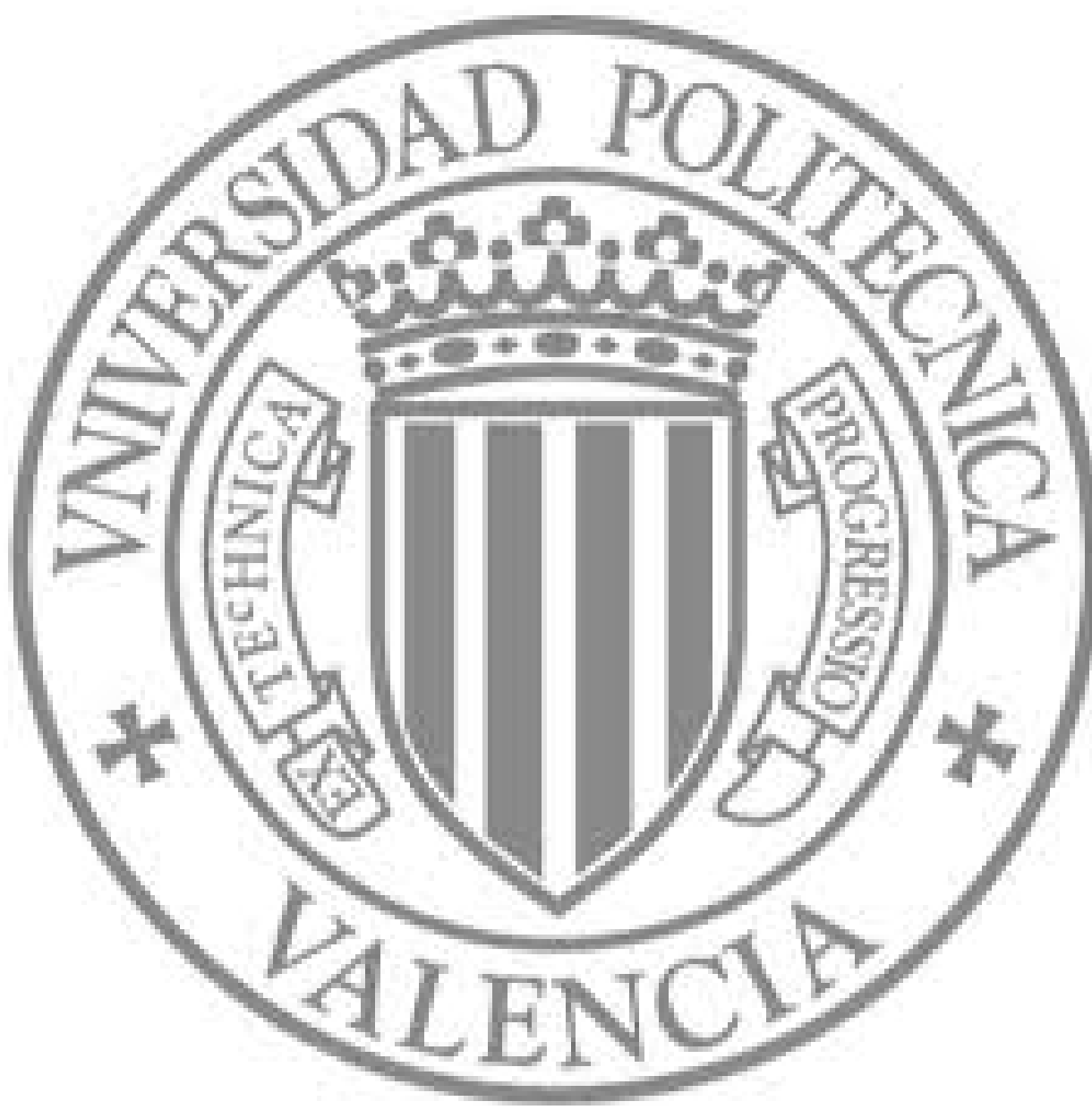

The final publication is available at

http://link.springer.com/article/10.1007\%2Fs11365-012-0242-3

Copyright Springer Verlag (Germany) 


\title{
International Entrepreneurship in SMEs: A Study of Influencing Factors in the Textile Industry
}

\author{
Gil-Pechuán, Ignacio ${ }^{1}$, Expósito-Langa, Manuel ${ }^{2}$, Tomás-Miquel, José-Vicente ${ }^{3}$ \\ Business Administration Department \\ Universitat Politècnica de València \\ Valencia (Spain) \\ ${ }^{1}$ Email: igil@doe.upv.es \\ ${ }^{2}$ Email: maexlan@doe.upv.es \\ ${ }^{3}$ Email: jotomi@doe.upv.es
}

\begin{abstract}
International entrepreneurship is an incipient research area with a rapidly increasing body of knowledge and contributions. An important part of this literature has focused on the analysis of the contributing factors to IE development. From these studies, this work attempts to analyse and validate through an integrative model the effect on this construct in SME of some of the main factors proposed by the literature such as Skills and Competences, Attitude and Proactiveness, Creativity and Innovation, Networking, Employees and Activity. To proceed with this aim, we conducted an empirical research focused on 174 textile SME in Spain. The results obtained confirm a positive relationship between the studied factors and the IE development. In consequence, this work agrees with previous literature that point out the need to use multi-theoretical perspectives, combining multiple factors.
\end{abstract}

Keywords: International Entrepreneurship, SME, Textile Industry

\section{Introduction}

International Entrepreneurship (IE) is a topic which is of interest to academics, business people, and governments around the world. According to Zahra \& George (2002) this term first appeared in a short article by Morrow (1988).

IE research emerged as a response to the dynamic nature of newly internationalising firms, which is perceived as being anomalous to the traditional patterns of firm internationalisation (Oviatt \& McDougall, 1994; McDougall et al., 1994).

Businesses in an increasing number of countries are seeking international competitive advantage through entrepreneurial innovation (Simon, 1996). Many national governments are striving for improved living standards for their citizens through the discovery and acquisition of new technologies and through attempts to 
replicate regional entrepreneurial aggregations. Academics are observing accelerated internationalization even among the smallest and newest organizations (Oviatt \& McDougall, 1999). The use of efficient worldwide communications technology and transportation, the decrease in governments' protectionist policies, and the resulting decrease in the number of geographically protected market niches have made it possible if not necessary, for many of today's entrepreneurial firms to view their operating domains as international. The upshot is that the intersection of international business and entrepreneurship is of increasing importance for all those interested in either topic.

In this paper, our contribution is to empirically validate some of the influencing factors on International Entrepreneurship in SMEs extracted from the extensive research literature (Peiris et al., 2012) such as Skills/Competences, Attitude/Proactiveness, Creativity and Innovation, Networking, Employees and Activity.

The paper is structured as follows. First, we explain the theoretical framework and the derived hypotheses. We then describe the research method and findings. Finally, we outline its possible contribution and implications.

\section{Theoretical framework and hypotheses}

\section{Skills and International Entrepreneurship}

The first variable in our model is use of knowledge (Skills/Competences) as a key influencing factor in the willingness to undertake projects internationally. Oviatt and
McDougall

(1994)

identify

Skills/Competences as a major resource and one of the four necessary and sufficient elements in their proposed model for sustainable international new ventures. Developing skills and knowledge has been identified as a key source of international competitive advantage by several scholars (for example, Autio et al., 2000; Bell et al., 2003; Coviello and McAuley, 1999; Jones, 1999). McNaughton (2001, 2003) found that knowledge-intensive firms achieved a wider reach in international markets and a faster pace of internationalization.

In their study on the learning advantages of newness, Autio et al. (2000) identify two reasons which make it possible to "amplify" the intensity of internationalization through the competences generated:

Firstly, companies that focus on building competences based on training and their use as a source of competitive advantage are more likely to develop learning skills that are helpful for adaptation and successful growth in international environments than companies that are more dependent on tangible resources. Secondly, because the knowledge gained is a mobile resource since it can be combined with existing fixed assets such as distribution channels or manufacturing resources in foreign markets at relatively low prices (Liebeskind, 1996; McDougall et al., 1994). This means that companies committed to obtaining competences based on greater knowledge can take advantage of greater international growth opportunities and with greater flexibility through such combinations. Hence companies that develop competences through the 
intensive use of knowledge are less limited by distance or national borders (Autio et al., 2000, p. 913).

In our research we explore the role of the acquisition of knowledge-based skills and competences on international entrepreneurship development.

Thus, we propose:

Hypothesis 1: Skills/Competences will be positively associated with International Entrepreneurship.

\section{Attitude, Creativity and Innovation for} International Entrepreneurship

Success in global business operations requires creativity, ingenuity and calculated risk-taking (Bossak \& Nagashima 1997), because domestic strengths do not always guarantee success in foreign markets $(\mathrm{Hu}, 1995$; Vlasic, 1998). Consequently, when expanding internationally, U.S. companies have explored new models of production, management, $R \& D$, human resources, and marketing systems (Bannon, 1998; Porter, 1990). They have also learned and utilized different skills from those that have been used in their home markets (Smart, 1996; Williamson, 1997). Developing and exploiting these capabilities requires experimentation and risk-taking (McGrath et al., 1995; Shama, 1995). Entrepreneurial activities are, therefore, closely linked to firms' global operations (Dean et al., 1993).

The continuing globalization of business provides an important opportunity to study Spanish companies' entrepreneurial activities in international markets. Even though the motivations for, and effects of, these global activities have been explored from economic and organizational perspectives, they have rarely been viewed through an entrepreneurial lens. This paper fills this gap in the literature by examining Spanish firms' corporate entrepreneurship (CE) activities in international markets. Even though entrepreneurial activities might permeate every aspect of a firm's operations (Pinchot, 1985; Zahra, 1991), this study focuses on CE undertaken primarily in a company's international operations. We refer to these activities as Attitude/Proactiveness towards international corporate entrepreneurship (ICE). This study views ICE as being highly influenced by the sum of a company's innovation, risk-taking, and proactiveness (Miller, 1983; Covin \& Slevin, 1989; Zahra, 1991). These activities usually seek to increase the firm's innovativeness, adaptation, and agile strategic responses to changes in the external environment. Innovation refers to the firm's ability to create new products and successfully introduce them to the market. It also indicates the company's commitment to process and organizational innovations (Zahra, 1993a). Proactiveness shows a firm's aggressive pursuit of market opportunities and a strong emphasis on being among the very first to undertake innovations in its industry. Risk-taking is defined as the firm's disposition to support innovative projects (e.g., international ventures), even when the payoff from these activities is uncertain. Collectively, these activities can enhance the company's ability to recognize and exploit international market opportunities well ahead of its competitors.

In consequence, we propose the following two hypotheses: 
Hypothesis 2: Attitude/Proactiveness will be positively associated with International Entrepreneurship.

Hypothesis 3: Creativity and Innovation will be positively associated with International Entrepreneurship.

\section{Networking and International \\ Entrepreneurship}

Companies need to combine entrepreneurial and strategic behaviour at the same time.

While business strategy involves actions or commitments to generate competitive advantage, entrepreneurship means creation. That is to say, strategic management consists of deciding how to maintain and sustain a competitive advantage based on something that has already been created. Hence the business factor, namely entrepreneurship, and strategic management focus on how companies adapt to changes in their environments and exploit opportunities created by discontinuities and uncertainty (Hitt et al., 2001).

We know little about the process of innovation in companies and even less in SMEs. The first incentive is market pressure, in other words competition is much more important than grants. An innovator's motives are more precise than those of a researcher (implementation, fulfilment, performance, service, emulation, etc.) because they seek to create value and are aware that every innovation provides a temporary competitive advantage, which means they have to keep on innovating.

Consequently it is important for SMEs to establish stable links and partnerships with research organizations and other companies. This will transfer and redirect the return on the research potential of our universities and enable technology transfer offices to operate as entrepreneurship sales centres. This will showcase their know-how through research contracts with companies, cooperation with technology parks and centres, the mobility of researchers and experts and the founding of innovative companies.

Accordingly, we can propose:

Hypothesis 4: Networking will be positively associated with International Entrepreneurship.

\section{Entrepreneurship and International Performance}

International entrepreneurial orientation reflects the firm's overall proactiveness and aggressiveness in its pursuit of international markets. It is associated with managerial vision, innovativeness, and proactive competitive posture overseas (Khandwalla, 1977; Miller \& Friesen, 1984; Covin \& Slevin, 1989; Davis et al., 1991). It reflects the firm's propensity to engage in innovative, proactive, and risk-seeking behaviours in order to achieve competitive and strategic objectives. The innovative dimension refers to the pursuit of creative or novel solutions to challenges confronting the firm, including the development or enhancement of products and services, as well as new administrative techniques and technologies for performing organizational functions (e.g., production, marketing, sales, and distribution). For example, most key informants described how an entrepreneurial mindset was critical to 
undertaking the generally challenging activities associated with entering a new foreign market. Proactiveness is the opposite of reactiveness and relates to aggressive posturing relative to competitors, with emphasis on execution and follow-up of tasks in pursuit of the firm's objectives. Risk-seeking involves the planning and implementation of projects entailing significant chances of costly failure (Khandwalla, 1977; Miller \& Friesen, 1984; Davis et al., 1991).

More generally, entrepreneurial orientation is a fundamental posture, potentially applicable to any firm and instrumental to strategic innovation (Miles \& Snow, 1978; Miller \& Friesen, 1984; Covin \& Slevin, 1991). Studies have found a positive association between entrepreneurship and expansion of strategic activities (Miller \& Friesen, 1984; Davis et al., 1991), and between entrepreneurship and organizational performance (Snow and Hrebiniak, 1980; Miller \& Friesen, 1984; Covin \& Slevin, 1991). Management at substantially entrepreneurial firms may be more inclined than others to create and activate strategies and tactical manoeuvres with a view to maintaining or improving performance. This notion appears to be true for companies operating in foreign markets as well as at home.

It is generally asserted that entrepreneurship can have a positive influence on the performance of the firm (Covin \& Slevin, 1991). Yet, although entrepreneurship is considered to be a driving factor for value creation in both international and domestic markets, there seems to exist a paucity of empirical studies on the entrepreneurship-performance relationship (Zahra, 1993b; Zahra et al., 1999). This holds especially for studies dealing with entrepreneurship and international performance of the firm. Researchers suggest that this association is positive (McDougall \& Oviatt, 2000; Dimitratos \& Plakoyiannaki, 2003), however empirical evidence is scant. Given the importance of entrepreneurship to researchers, business managers and policy makers, understanding its role in the environmental conditions of the international and domestic domain for superior organizational performance abroad is a significant and timely research objective.

There is no unanimity among researchers on the terms used to describe entrepreneurial behaviour, as Zahra et al. (1999) conclude in their literature review. In order to capture the organizational processes and methods that firms employ when acting entrepreneurially, authors use the labels of entrepreneurial posture (Covin \& Slevin, 1991), entrepreneurial orientation (Lumpkin \& Dess, 1996), entrepreneurial style (Naman \& Slevin, 1993), entrepreneurial management (Stevenson \& Jarillo, 1990), entrepreneurial strategy making (Dess et al., 1997) or, most often, Miller's (1983) term of entrepreneurship (e.g. Zahra et al., 1999).

In relation to the other key notion of this present study, performance is a construct that is difficult to operationalize holistically as it may refer to different aspects of the organizational effectiveness of the firm (Dess \& Robinson, 1984; Venkatraman \& Ramanujam, 1986). In their literature review of entrepreneurship studies, Murphy et al. 
(1996) concur with this statement presenting results of studies that employ a wide variety of objective and subjective performance measures.

Consequently, we propose:

Hypothesis 5: International Performance will be positively associated with International Entrepreneurship.

\section{Method}

The textile industry is one of the most complex manufacturing industries, involving a great number of activities from yarn production to fabric or knitwear for the final customer. The textile industry in 2011 in Spain accounted for $6 \%$ of industrial employment, $3 \%$ of GDP and $5.9 \%$ of Spanish industrial exports. Globalization pressures, such as textile trade liberalization, have considerably affected the textile industry. Additionally, in the face of increasing competition from countries with emerging economies, European firms have reacted with a variety of strategies, including productive delocalization aimed at reducing production costs, policies of repositioning in higher quality segments of the market, with more added value products and services, and also intense international entrepreneurship.

\subsection{Sample collection and data sources}

The population of this empirical study has been drawn from Valencian textile industry firms in Spain. The Valencian textile industry focuses on the so-called home textile sector and represents $17 \%$ of the Spanish textile industry, providing employment for over 24,000 people, with a turnover of $€ 1,920$ million euros and exports worth $€ 693$ million.
Questionnaires were used as primary data sources and the fieldwork was carried out over the period from January to March 2012. The identification of companies was done through the $\mathrm{SABI}^{1}$ database, which also allowed us to control some of the questionnaire answers.

Once the initial list of textile companies was obtained, we refined it by removing those companies that showed excessive heterogeneity, e.g. in their size (firms with less than 5 employees) or in the production process (dressmaking firms).

Prior to questionnaire distribution we ran a pilot questionnaire with five selected respondents that we considered representative of the whole sample. Finally, the questionnaire responses were obtained through personal interviews. Respondents were required to have a global knowledge of the company i.e. they were either the General Manager or wer part of the Management Staff.

A total of 174 complete and corrected questionnaires accounting for $24 \%$ per cent of the population were obtained. Using the Student's $t$-test we checked possible biases between the sample and the population. To do this, we carried out a test on the size of the companies. We used the SABI database as a source for this information. As Table 1 demonstrates, there was no bias between the sample and the population.

1 SABI is a directory of Spanish and Portuguese companies that collects general information and financial data. In the case of Spain, it has collected more than $95 \%$ of the companies in the 17 Spanish regions with total yearly revenues of over $€ 360,000-€ 420,000$. 


\section{(INSERT TABLE 1 ABOUT HERE)}

\subsection{Measures}

We carried out this study using some basic variables. We reviewed previous research to generate measuring procedures and adapted them to the particular context of our empirical setting.

\subsubsection{Dependent variable}

International Entrepreneurship. Following Styles \& Seymour's (2006) definition of IE we assessed the degree of creation and exchange of value through the identification and exploitation of opportunities that cross national borders. We asked firms to evaluate internationalization projects over the last five years, such as international promotion actions, new market prospection, new international venture creation and international business.

\subsubsection{Independent variables}

Skills/Competences. Human capital in international ventures is becoming increasingly important. Firms focusing on knowledge, skills and competences are more likely to be successful in adapting to new environments, such as as international markets, than firms which are more dependent on tangible resources. Thus, knowledge-intensive firms are less constrained by distance or national boundaries (Autio et al., 2000). Thus, we asked how many graduates with technical competences there were in the workforce.

Attitude/Proactiveness. International entrepreneurship involves risk-taking, proactiveness and innovative behaviours since it allows national boundaries to be crossed (Coviello and Jones, 2004; Zhou, 2007). An innovation culture can drive products and technology-based advantages to contribute to the superior performance of born-global internationalization (Zhou, 2007). In this sense, respondents were asked about participating in nationals R\&D programmes or in European Competitiveness and Innovation Framework Programmes in the last five years.

Creativity and Innovation. This variable has long been a core focus for entrepreneurship researchers (Styles \& Seymour, 2006). Creativity and Innovation facilitate the firm's willingness and ability to engage in international markets. In fact, Kropp et al. (2006) state that creativity and innovation are critical to international entrepreneurial business ventures. Other authors (Knight and Cavusgil, 2004) found that innovative products and quality improved international orientation. In consequence, we asked about their results in creation and innovation through new designs, new material and fibres used in production processes, new applications and new products in the last five years.

Networking. Networking is a powerful tool for the entrepreneur (Dubini \& Aldrich, 1991; Oviatt \& McDougall, 2005). The internationalization processes of entrepreneurial firms are enriched through network contacts, rather than solely from the strategic managerial decisions. Thus, networks can help entrepreneurs identify international opportunities and cooperative strategies (Oviatt \& McDougall, 2005). We asked firms to evaluate the perception obtained from the cooperation agreements established with universities, technological centres, trade associations and others firms in international projects. 
International Performance. International sales as a percentage of total sales are the most widely used measure to capture the effectiveness of international performance (Zhou, 2007; Yeoh, 2004). Respondents were asked about the percentage of their foreign sales against their total sales on a seven-point scale.

Employees. Size is usually used as a control variable in studies of IE (Peiris et al., 2012). The variable has been measured through the number of employees.

Activity. We identified the sample companies according to their activity (commercial or manufacturing). To do this, we built a dummy variable in order to show different behaviours depending on the main activity they carried out.

\section{Results}

To test the hypotheses we ran a stepwise hierarchical regression approach to assess the explanatory power of each variable. To compute all models we used the statistics software SPSS version 20.

We performed various regression equation analyses, which are shown in Table 2. In each regression model, variables were progressively introduced in order to analyze the improvement in their fit and significance level. We previously validated all multi-item scales with an exploratory factor analysis.

Model 1 presents the base case controlling firm size (Employees) and Activity. Neither Employees nor Activity was significantly associated with IE. These results were expected since previous literature (Peiris et al., 2012) revealed that, for instance, IE was not dependent on firm size. Additionally, the dummy variable had no significant association with IE. After introducing Model 1, Table 2 shows the results of the model regression contrasting the hypotheses we proposed. All five hypotheses were supported. In all cases, the F-statistic result confirmed the significance of the variance of the dependent variable through the models. Finally we obtained an Adjusted $\mathrm{R}^{2}$ of (.389), a value that we consider acceptable to complete an integrative view of IE that focuses on concepts related to employee profile, innovation attitude and a proactive context, cooperation and previous experiences in the firm.

\section{(INSERT TABLE 2 ABOUT HERE)}

\section{Conclusions}

The research stream on IE offers great opportunities for scholars to employ and integrate theories from multiple disciplines (Zahra \& George, 2002). IE behaviour is a complex social phenomenon that requires different types of resources to identify and exploit opportunities (Peiris et al., 2012). Thus, this work was based on providing a comprehensive picture of the resources that influence IE. Specifically, we have emphasized the importance of integrating entrepreneurial competencies, social networks and innovation factors. In our view, this paper contributes to IE literature because it combines multiple factors and has obtained the importance of each category in IE. Additionally, the paper's contribution is in line with authors who point out the need to use multi-theoretical perspectives (Zahra \& George, 2002; Jones \& Coviello, 2005). 
The results obtained show how important it is for international entrepreneurs to have a team with the right skills to tackle new international ventures. Thus, having workers with adequate skills is necessary for the firm to adapt to new scenarios in international markets. In addition, the findings highlight the importance of developing an innovative attitude and innovative products, resulting in superior international market ventures. IE firms are more innovative in their strategic decisions, reflecting their behavioural characteristics (McDougall \& Oviat, 2000). It is important to note that an ability to network characterises IE in the born-global firm and plays a key role. Networking allows companies to access new sources of quality information and knowledge. Finally, a business's international performance is essential to encourage companies to undertake new ventures in international markets. Therefore, we find a positive association between IE and international performance, as suggested in McDougall \& Oviatt (2000) or Dimitratos \& Plakoyiannaki (2003). Firms influenced by previous positive experiences are more likely to seek markets in the born global context.

Our paper presents some limitations that we shall attempt to approach in future research. Firstly, we have only considered one industry. Thus we must be cautious when generalizing results and conclusions. It may be of interest to analyse how other cases vary in greater depth. Secondly, since the IE process can take a long time, it may be advantageous to undertake a longitudinal study that could track the entire time span from the early stages to the achievement of results in the company. Thirdly, it would be interesting to carry out a more detailed study in entrepreneurial companies. This would enable us to compare their role in local markets, their customer or supplier profiles and their product portfolio to name but a few. However, we must leave these limitations for future studies.

\section{References}

Autio, E., Sapienza, H.J., \& Almeida, J.G. (2000). Effects of age at entry, knowledge intensity, and imitability on international growth. Academy of Management Journal, 43, 909-924.

Bannon, L. (1998). Mattel plans to double sales abroad. Wall Street Journal, February 11, (A3 and A8).

Bell, J., McNaughton, J., Young, R., \& Crick, D. (2003). Towards an integrative model of small firm internationalisation. Journal of International Entrepreneurship, 1, 339-362.

Bossak, J. \& Nagashima, S. (1997). Corporate Strategies for a Borderless World: Sharpening your Competitive Edge, Asian Productivity Organization, Tokyo, Japan.

Coviello, N.E. \& Jones, M.V. (2004). Methodological issues in international entrepreneurship research. Journal of Business Venturing, 19, 485-508.

Coviello, N.E. \& McAuley, A. (1999). Internationalization and the smaller firm: A review of contemporary empirical research. Management International Review, 39, 223-256. 
Covin, J. \& Slevin, D. (1989). Strategic management of small firms in hostile and benign environments. Strategic Management Journal, 10(1), 75-87.

Covin, J. \& Slevin, D. (1991). A conceptual model of entrepreneurship as firm behavior. Entrepreneur. Theory Pract., 16, 7-25.

Davis, D., Morris, M. \& Allen, J. (1991). Perceived environmental turbulence and its effect on selected entrepreneurship, marketing, and organizational characteristics in industrial firms. J. Acad. Mark. Sci., 19(1), 43-51.

Dean, C.C., Thibodeaux, M.S., Beyerlein, M., Ebrahimi, B. \& Molina, D. (1993). Corporate entrepreneurship and competitive aggressiveness. A comparison of U.S. firms operating in eastern Europe and the Commonwealth of Independent States with U.S. firms in other high-risk environments. Advances in International Comparative Management, 8, 31-54.

Dess, G.G., Lumpkin, G.T. \& Covin, J.G. (1997). Entrepreneurial strategy making and firm performance: tests of contingency and configurational models. Strategic Management Journal, 18, 677-695.

Dess, G.G. \& Robinson, R.B. (1984). Measuring organizational performance in the absence of objective measures: the case of privately held firms and conglomerate business units. Strategic Management Journal, 5, 265-273.

Dimitratos, P. \& Plakoyiannaki, E. (2003). Theoretical foundations of an international entrepreneurial culture. Journal of International Entrepreneurship, 1, 187-215.

Dubini, P. \& Aldrich, H. (1991). Personal and extended networks are central to the entrepreneurial process. Journal of Business Venturing, 6, 305-313.

Hitt, M.A., Ireland, R.D., Camp, S.M. \& Sexton, L.D. (2001). Strategic entrepreneurship: entrepreneurial strategies for wealth creation [Special Issue], Strategic Management Journal, 22 (6), 479-492.

Hu, Y.-S. (1995). The international transferability of competitive advantage. California Management Review, 37(4), 73-88. Jones, M.V. (1999). The internationalization of small UK high technology based firms. Journal of International Marketing, 7, $15-41$.

Khandwalla, P. (1977). The Design of Organizations. New York: Harcourt Brace Jovanovich.

Knight, G.A. \& Cavusgil, S.T. (2004). Innovation, organization capabilities, and the born-global firm. Journal of International Business Studies, 35, 124-141.

Kropp F., Lindsay N.J., Shoham A. (2006). Entrepreneurial, market, and learning orientations and international entrepreneurial business venture performance in South African firms. Int. Mark. Rev. 23(5), 504-523.

Liebeskind, J.P. (1996). Knowledge, strategy, and the theory of the firm. Strategic Management Journal, 17, 93-107.

Lumpkin, G.T. \& Dess, G.G. (1996). Clarifying the entrepreneurial construct and 
linking it to performance. Academy of Management Review, 21, 135-172.

McDougall, P.P. \& Oviatt, B.M. (2000). International entrepreneurship: the intersection of two research paths. Academy of Management Journal, 43, 902-908.

McDougall, P.P., Shane, S., \& Oviatt, B.M. (1994). Explaining the formation of international new ventures: The limits of theories from international business research. Journal of Business Venturing, 9, 469-487.

McGrath, R.G., MacMillan, I.C. \& Venkataraman, S. (1995). Global dimensions of new competencies. In Birley, S. \& MacMillan, I.C., International Entrepreneurship, New York: Routledge.

McNaughton, R.B. (2001). The export mode decision-making process in small knowledgeintensive firms. Market Intelligence and Planning, 19, 12-20.

McNaughton, R.B. (2003). The number of export markets that a firm serves: Process models versus the born-global phenomenon. Journal of International Entrepreneurship, 1, 297-311.

Miles, R.E. \& Snow, C.C. (1978). Organizational Strategy, Structure and Process. New York: McGraw-Hill.

Miller, D. (1983). The correlates of entrepreneurship in three types of firms. Management Science, 29(7), 770-791.

Miller, D. \& Friesen, P. (1984). Organizations: A Quantum View. Englewood Cliffs, NJ: Prentice-Hall.
Morrow, J.F. (1988). International entrepreneurship: A new growth opportunity. New Management, 3, 59-61.

Murphy, G.B., Trailer, J.W. \& Hill, R.C. (1996). Measuring performance in entrepreneurship research. Journal of Business Research, 36. 15-23.

Naman, J.L. \& Slevin, D.P. (1993). Entrepreneurship and the concept of fit: a model and empirical tests. Strategic Management Journal, 14, 137-153.

Oviatt, B.M. \& McDougall, P.P. (1994). Toward a theory of international new ventures. Journal of International Business Studies, 25(1), 45-64.

Oviatt, B.M. \& McDougall, P.P. (1999). A framework for understanding accelerated international entrepreneurship. In R. Wright (Ed.), Research in global strategic management (pp. 23-40). Stamford, CT: JAI Press.

Oviatt, B.M. \& McDougall, P.P. (2005). Defining international entrepreneurship and modeling the speed of internalization. Entrepreneurship Theory \& Practice, 29 (5), 537-554.

Peiris, I.K., Akoorie, M.E.M \& Sinha, P.N. (2012). International entrepreneurship: A critical analysis of studies in the past two decades and future directions for research. Journal of International Entrepreneurship. Article in press.

Pinchot III, G. (1985) Intrapreneuring: Why you don't have to leave the corporation to become entrepreneur. New York: Harper and Row Publishers. 
Porter, M. (1990). The competitive advantage of nations. London: Collier-Macmillan.

Shama, A. (1995). Entry strategies of U.S. firms to the former Soviet Bloc and Eastern Europe. California Management Review, 37(3), 90-109.

Simon, H. 1996. Hidden champions: Lessons from 500 of the world's best unknown companies. Boston: Harvard Business School Press.

Smart, T. 1996. GE's Welch: 'Fighting Like Hell to be No. 1'. Business Week, July 8, 48.

Snow, C. \& Hrebiniak, L. (1980). Strategy, distinctive competence, and organizational performance. Adm. Sci. Q., 25, 317-336.

Stevenson, H.H. \& Jarillo, J.C. (1990). A paradigm of entrepreneurship: entrepreneurial management. Strategic Management Journal, $11,17-27$.

Styles, C. \& Seymour, R.G. (2006). Opportunities for marketing researchers in international entrepreneurship, International Marketing Review, 23 (2), 126-145.

Venkatraman, N. \& Ramanujam, V. (1986). Measurement of business performance in strategy research: a comparison of approaches. Academy of Management Review, 11, 801-814.

Vlasic, B. (1998). The little car that could carry Chrysler overseas. Business Week, January 19, 39.

Williamson, P.J. (1997). Asia's new competitive game. Harvard Business Review, 75(5), 55-67.

Yeoh, P.L. (2004). International learning: Antecedents and performance implications among newly internationalizing companies in an exporting context. International Marketing Review, 21 (4/5), 511-535.

Zahra, S.A. (1991). Predictors and financial outcomes of corporate entrepreneurship. An exploratory study. Journal of Business Venturing, 6(4), 259-285.

Zahra, S.A. (1993a). Environment, corporate entrepreneurship and financial performance. A taxonomic approach. Journal of Business Venturing, 8(4), 319-340

Zahra, S.A. (1993b). A conceptual model of entrepreneurship as firm behavior: a critique and extensión. Entrepreneurship Theory and Practice, 17(4), 5-21.

Zahra S.A. \& George G. (2002). International entrepreneurship: the current status of the field and future agenda. In Hitt M.A., Ireland R.D., Camp S.M. \& Sexton D.L., Strategic entrepreneurship: creating a new mindset, Oxford: Blackwell Publishers.

Zahra, S.A., Jennings, D.F. \& Kuratko, D.F. (1999). The antecedents and consequences of firm-level entrepreneurship: the state of the field. Entrepreneurship Theory and Practice, 24(2), 45-63.

Zhou, L. (2007). The effects of entrepreneurial proclivity and foreign market knowledge on early internationalization. Journal of World Business, 42 (3), 281-293. 
Table 1. t-student for mean comparison.

\begin{tabular}{lcccc}
\hline Variables & $\begin{array}{c}\text { Value of } \\
\text { the test }\end{array}$ & $\mathrm{t}$ & $\begin{array}{c}\text { Sig. } \\
\text { (bilateral) }\end{array}$ & $\begin{array}{c}\text { Mean } \\
\text { differences }\end{array}$ \\
\hline Number of & 32 & -.835 & .405 & -2.144 \\
employees & & & & \\
\hline
\end{tabular}

Table 2. Results of multiple hierarchical regression analysis

\begin{tabular}{|c|c|c|c|c|c|c|}
\hline \multicolumn{7}{|c|}{ Dependent variable: International Entrepreneurship } \\
\hline & Model 1 & Model 2 & Model 3 & Model 4 & Model 5 & Model 6 \\
\hline Constant & $1.285(.161)^{*}$ & $1.028(.170)^{*}$ & $.932(.166)$ & $.648(.178)$ & $.578(.172)$ & $.236(.173)$ \\
\hline Skills/Competences & & $.810(.220)^{* *}$ & $.695(.215)^{* *}$ & $.614(.208)^{* *}$ & $.610(.200)^{* *}$ & $.563(.186)^{* *}$ \\
\hline Attitude/Proactiveness & & & $.273(.073)^{* *}$ & $.196(.074)^{*}$ & $.071(.100)$ & $.169(.095)^{*}$ \\
\hline Creativity and & & & & $.316(.086)^{* *}$ & $.303(.083)^{* *}$ & $.230(.078)^{* *}$ \\
\hline \multicolumn{7}{|l|}{ innovation } \\
\hline Networking & & & & & $.736(.194)^{* *}$ & $.673(.180)^{* *}$ \\
\hline International & & & & & & $.384(.073)^{* *}$ \\
\hline \multicolumn{7}{|l|}{ performance } \\
\hline Employees (control) & $.010(.003)$ & $.007(.003)$ & $.000(.004)$ & $-.001(.003)$ & $-.002(.003)$ & $-.003(.003)$ \\
\hline Activity (control) & $-.156(.204)$ & $-.170(.197)$ & $-.153(.190)$ & $-.065(.185)$ & $-.072(.178)$ & $.035(.167)$ \\
\hline Model $F$ & $5.637 *$ & $13.532 * *$ & $13.851^{* *}$ & $13.505 * *$ & $14.427 * *$ & $27.653 * *$ \\
\hline$R^{2}$ & .062 & .131 & .197 & .257 & .316 & .413 \\
\hline Adjusted $R^{2}$ & .051 & .116 & .178 & .234 & .291 & .389 \\
\hline$R^{2}$ Change & - & $.069 * *$ & $.066 * *$ & $.060 * *$ & $.059 * *$ & $.098 * *$ \\
\hline
\end{tabular}

$\mathrm{N}=174 ; p<.01 * * ; p<.05^{*}$ Non standard coefficients (errors in brackets) 